\title{
Evaluation of $\mathrm{UF}_{6}$-to- $\mathrm{UO}_{2}$ Conversion Capability at Commercial Nuclear Fuel Fabrication Facilities
}

Environmental Assessment Division Argonne National Laboratory

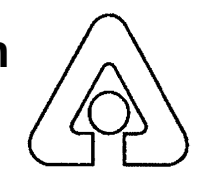

Operated by The University of Chicago, under Contract W-31-109-Eng-38, for the

United States Department of Energy 


\section{Argonne National Laboratory}

Argonne National Laboratory, with facilities in the states of Illinois and Idaho, is owned by the United States Government and operated by The University of Chicago under the provisions of a contract with the Department of Energy.

This technical memorandum is a product of Argonne's Environmental Assessment Division (EAD). For information on the division's scientific and engineering activities, contact:

Director, Environmental Assessment Division

Argonne National Laboratory

Argonne, Illinois 60439-4832

Telephone (630) 252-3107

Presented in this technical memorandum are preliminary results of ongoing work or work that is more limited in scope and depth than that described in formal reports issued by the EAD.

Publishing support services were provided by Argonne's Information and Publishing Division (for more information, see IPD's home page: http://www.ipd.anl.gov/).

\section{Disclaimer}

This report was prepared as an account of work sponsored by an agency of the United States Government. Neither the United States Government nor any agency thereof, nor The University of Chicago, nor any of their employees or officers, makes any warranty, express or implied, or assumes any legal liability or responsibility for the accuracy, completeness, or usefulness of any information, apparatus, product, or process disclosed, or represents that its use would not infringe privately owned rights. Reference herein to any specific commercial product, process, or service by trade name, trademark, manufacturer, or otherwise does not necessarily constitute or imply its endorsement, recommendation, or favoring by the United States Government or any agency thereof. The views and opinions of document authors expressed herein do not necessarily state or reflect those of the United States Government or any agency thereof, Argonne National Laboratory, or The University of Chicago. 
Evaluation of $\mathrm{UF}_{6}$-to- $\mathrm{UO}_{2}$ Conversion Capability at Commercial Nuclear Fuel Fabrication Facilities

by N.L. Ranek and F.A. Monette

Environmental Assessment Division

Argonne National Laboratory, 9700 South Cass Avenue, Argonne, Illinois 60439

May 2001

Work sponsored by U.S. Department of Energy, Office of Environmental Management, Office of Site Closure, Oak Ridge Office, Oak Ridge, Tennessee 
This report is printed on recycled paper. 


\section{CONTENTS}

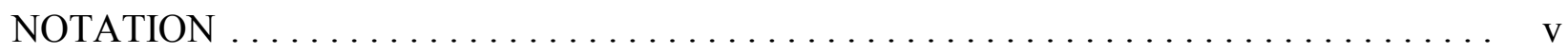

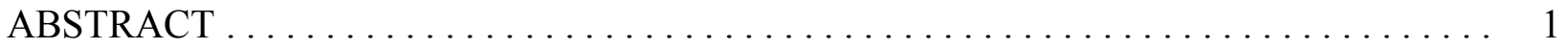

1 INTRODUCTION $\ldots \ldots \ldots \ldots \ldots \ldots \ldots \ldots \ldots \ldots \ldots \ldots \ldots \ldots \ldots \ldots \ldots \ldots \ldots \ldots \ldots$

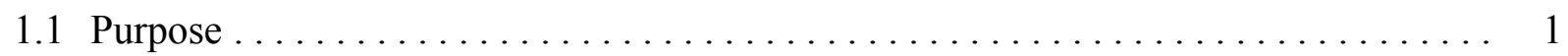

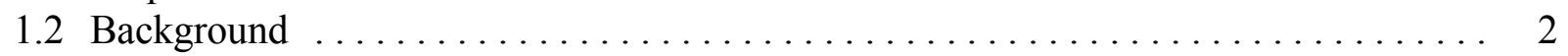

2 CHARACTERIZATION OF COMMERCIAL NUCLEAR FUEL

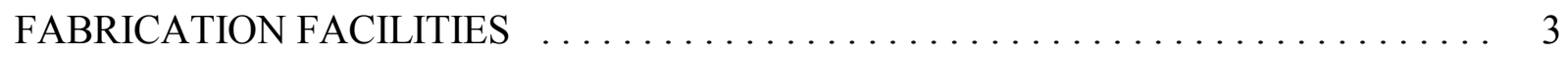

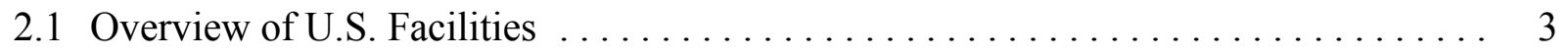

2.1.1 Westinghouse Electric Company LLC - Columbia Fuel

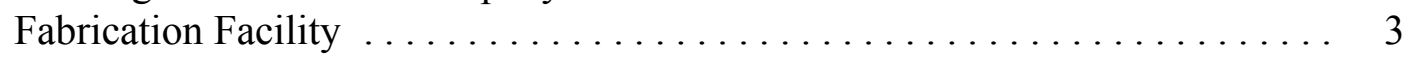

2.1.2 BWX Technologies, Inc. - Naval Nuclear Fuel Division . . . . . . . . . . 5

2.1.3 CE Nuclear Power LLC - Hematite Fuel Manufacturing Operations . . . . . . . . 7

2.1.4 Framatome ANP Richland, Inc. - Engineering and

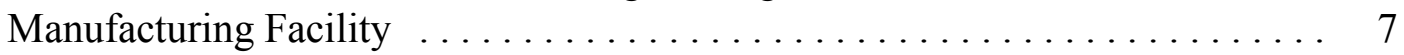

2.1.5 Framatome ANP, Inc. - Lynchburg Manufacturing Facility . . . . . . . . . . . 9

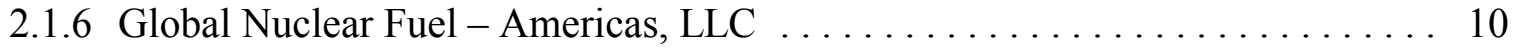

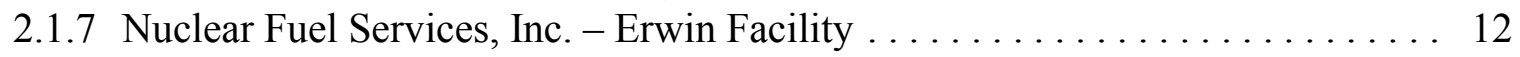

2.1 .8 Honeywell International - Metropolis Works $\ldots \ldots \ldots \ldots \ldots \ldots \ldots \ldots$

2.2 Overview of Non-U.S. Facilities $\ldots \ldots \ldots \ldots \ldots \ldots \ldots \ldots \ldots \ldots \ldots \ldots \ldots$

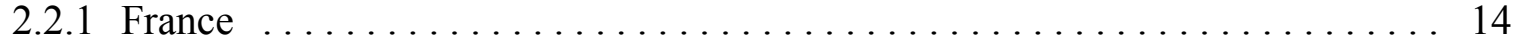

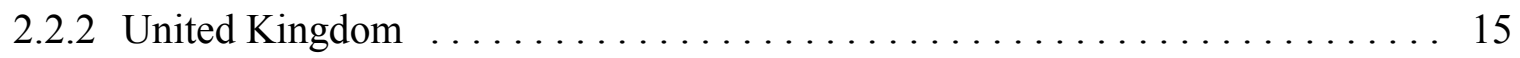

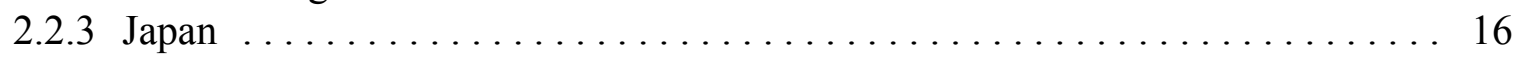

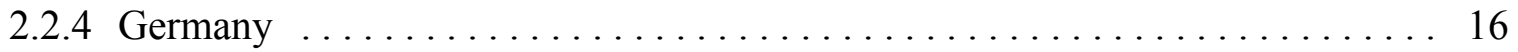

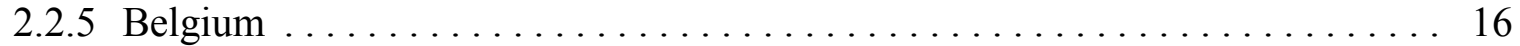

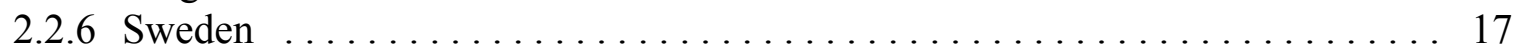

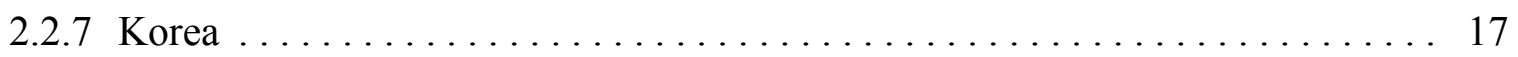

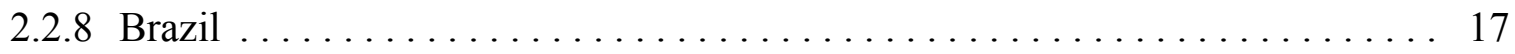

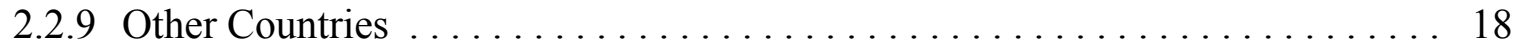

3 TRANSPORTATION $\ldots \ldots \ldots \ldots \ldots \ldots \ldots \ldots \ldots \ldots \ldots \ldots \ldots \ldots \ldots$

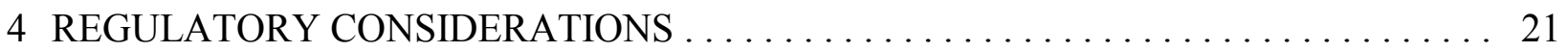

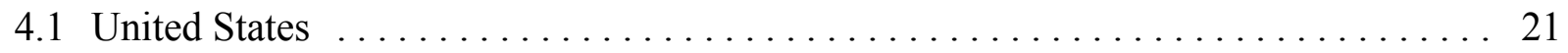

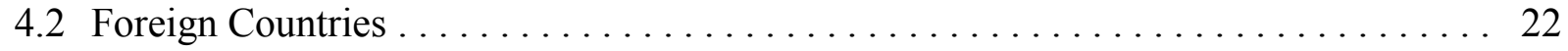

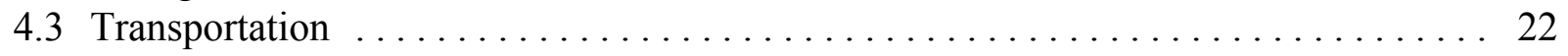

5 ANALYSIS AND CONCLUSIONS $\ldots \ldots \ldots \ldots \ldots \ldots \ldots \ldots \ldots \ldots \ldots \ldots$ 


\section{CONTENTS (Cont.)}

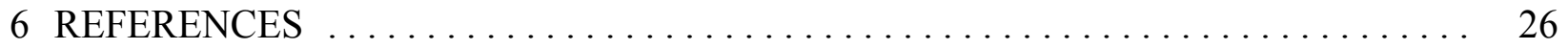

APPENDIX: Records of Telephone Survey $\ldots \ldots \ldots \ldots \ldots \ldots \ldots \ldots \ldots \ldots \ldots$ A -1

\section{TABLES}

1 Summary of $\mathrm{UF}_{6}$-to- $\mathrm{UO}_{2}$ Conversion Capabilities at U.S. Fuel

Fabrication Facilities and the Metropolis Works Pilot Plant ............... 4

2 Summary of $\mathrm{UF}_{6}$-to- $\mathrm{UO}_{2}$ Conversion Capabilities at Non-U.S. Fuel

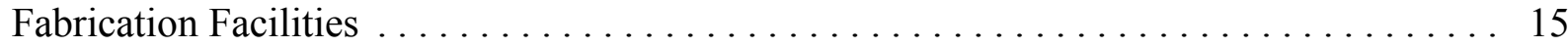

3 Summary of Transportation Route Distances from ETTP, Portsmouth, and Paducah to Commercial Fuel Fabricators $\ldots \ldots \ldots \ldots \ldots \ldots \ldots \ldots \ldots \ldots \ldots \ldots \ldots \ldots$ 


\section{NOTATION}

The following is a list of the acronyms and abbreviations, including units of measure, used in this report. Some abbreviations used only in tables are defined in those tables.

\begin{tabular}{|c|c|}
\hline $\mathrm{ABB}$ & Asea Brown Boveri \\
\hline $\mathrm{ADU}$ & ammonium diuranate \\
\hline AEA & Atomic Energy Act \\
\hline ANF & Advanced Nuclear Fuel BmbH \\
\hline ANP & Advanced Nuclear Power \\
\hline ANSI & American National Standards Institute \\
\hline AUC & ammonium uranyl carbonate \\
\hline $\mathrm{Bq} / \mathrm{g} \mathrm{U}$ & becquerel(s) per gram of uranium \\
\hline BWXT & BWX Technologies, Inc. \\
\hline CFFF & Columbia Fuel Fabrication Facility \\
\hline DOE & U.S. Department of Energy \\
\hline DOT & U.S. Department of Transportation \\
\hline EIA & Energy Information Administration \\
\hline ETTP & East Tennessee Technology Park (formerly the Oak Ridge K-25 site) \\
\hline FBFC & Franco-Belge de Fabrication de Combustibles \\
\hline FCF & Framatome Cogema Fuels \\
\hline $\mathrm{g}$ & $\operatorname{gram}(\mathrm{s})$ \\
\hline GE & General Electric \\
\hline GNF-A & Global Nuclear Fuel - Americas, LLC \\
\hline HEU & highly enriched uranium \\
\hline IAEA & International Atomic Energy Agency \\
\hline INB & Industrias Nucleares do Brasil \\
\hline $\mathrm{kg}$ & kilogram(s) \\
\hline KNFC & Korea Nuclear Fuel Co., Ltd. \\
\hline$: \mathrm{g}$ & $\operatorname{microgram}(\mathrm{s})$ \\
\hline $\mathrm{mCi}$ & millicurie(s) \\
\hline MNFC & Mitsubishi Nuclear Fuel Co., Ltd. \\
\hline NFS & Nuclear Fuel Services, Inc. \\
\hline NNFD & Naval Nuclear Fuel Division \\
\hline $\mathrm{NRC}$ & U.S. Nuclear Regulatory Commission \\
\hline psia & pound(s) per square inch absolute \\
\hline $\mathrm{Pu}$ & plutonium \\
\hline PWR & pressurized water reactor \\
\hline $\mathrm{SPC}$ & Siemens Power Corporation \\
\hline $\mathrm{tHM} / \mathrm{a}$ & metric ton(s) of heavy metal per annum \\
\hline $\mathrm{tU} / \mathrm{a}$ & metric ton(s) of uranium per annum \\
\hline $\mathrm{tUF}_{6} / \mathrm{a}$ & metric ton(s) of uranium hexafluoride per annum \\
\hline
\end{tabular}


$\mathrm{tUO}_{2} / \mathrm{a} \quad$ metric ton(s) of uranium dioxide per annum

U.S.

U-235

United States

$\mathrm{UF}_{6}$

235 isotope of uranium

$\mathrm{UO}_{2}$

uranium hexafluoride

$\mathrm{UO}_{3}$

uranium dioxide

$\mathrm{U}_{3} \mathrm{O}_{8}$

uranium trioxide

triuranium octaoxide (uranyl uranate)

WEC

Westinghouse Electric Corporation

$\mathrm{wt} \%$

weight percent 


\title{
EVALUATION OF UF -TO-UO $_{2}$ CONVERSION CAPABILITY AT COMMERCIAL NUCLEAR FUEL FABRICATION FACILITIES
}

by

\author{
N.L. Ranek and F.A. Monette
}

\begin{abstract}
This report examines the capabilities of existing commercial nuclear fuel fabrication facilities to convert depleted uranium hexafluoride $\left(\mathrm{UF}_{6}\right)$ to uranium oxide $\left(\mathrm{UO}_{2}\right)$. The U.S. Department of Energy (DOE) needs this information to determine whether using such capacity to convert DOE's inventory of depleted UF $_{6}$ to a more stable form is a reasonable alternative that should be considered in the sitespecific environmental impact statement for construction and operation of depleted $\mathrm{UF}_{6}$ conversion facilities. Publicly available information sources were consulted to ascertain the information summarized in this report. For domestic facilities, the information summarized includes currently operating capacity to convert depleted $\mathrm{UF}_{6}$ to $\mathrm{UO}_{2}$; transportation distances from depleted $\mathrm{UF}_{6}$ storage locations near Oak Ridge, Tennessee, Portsmouth, Ohio, and Paducah, Kentucky, to the facilities; and regulatory requirements applicable to nuclear fuel fabrication and transportation of depleted $\mathrm{UF}_{6}$. The report concludes that the total currently operating capability of U.S. commercial nuclear fuel fabricators to convert $\mathrm{UF}_{6}$ to $\mathrm{UO}_{2}$ is approximately 5,200 metric tons of $\mathrm{UF}_{6}$ per annum $\left(\mathrm{tUF}_{6} / \mathrm{a}\right)$. This total includes $666 \mathrm{tUF}_{6} / \mathrm{a}$ scheduled for shutdown by the end of 2001. However, only about $300 \mathrm{tUF}_{6} / \mathrm{a}$ of this capacity could be confirmed as being possibly available to DOE. The report also provides some limited descriptions of the capabilities of foreign fuel fabrication plants to convert $\mathrm{UF}_{6}$ to uranium oxide forms.
\end{abstract}

\section{INTRODUCTION}

\subsection{PURPOSE}

This report examines the capabilities of existing commercial nuclear fuel fabrication facilities to convert uranium hexafluoride $\left(\mathrm{UF}_{6}\right)$ to uranium dioxide $\left(\mathrm{UO}_{2}\right)$. The document includes information about current operating capacity for conversion of $\mathrm{UF}_{6}$ to $\mathrm{UO}_{2}$, information about transportation of depleted $\mathrm{UF}_{6}$ to facilities in the United States, and information about regulatory requirements applicable to nuclear fuel fabrication and depleted $\mathrm{UF}_{6}$ transportation. The U.S. Department of Energy (DOE) needs this information to determine whether using existing 
capacity at commercial fuel fabrication facilities to convert the inventory of depleted $\mathrm{UF}_{6}$ located at Oak Ridge, Tennessee, Paducah, Kentucky, and Portsmouth, Ohio, would be a reasonable alternative for consideration in the site-specific environmental impact statement for construction and operation of depleted $\mathrm{UF}_{6}$ conversion facilities.

\subsection{BACKGROUND}

Nuclear fuel fabrication is the final step in the process used to produce uranium fuel for commercial light-water nuclear power reactors. During fabrication, $\mathrm{UF}_{6}$ (typically enriched to between $2 \%$ and $5 \% \mathrm{U}-235$ ) is converted to $\mathrm{UO}_{2}$ powder. A ceramic process is then used to convert the $\mathrm{UO}_{2}$ powder to pellets, which are mechanically loaded into metal rods. The rods are then constructed into finished fuel assemblies for nuclear reactors.

In December 1998, nuclear fuel fabrication capacity existed at a total of 24 facilities in 13 countries. However, at that time, the world capacity for light-water reactor fuel fabrication was estimated at $150 \%$ of requirements, and significant consolidation was occurring, apparently as a result of widespread electric power industry restructuring. Faced with the cost of developing innovative products and services to continuously improve the performance of reactor fuel, some fabricators were choosing to exit the business or to seek mergers or joint venture partnerships (EIA 1998). This continuing trend is reflected in the information provided in this report about light-water reactor fuel fabricators in the United States.

Section 2 briefly describes each light-water reactor fuel fabrication facility located in the United States and provides information pertinent to assessing the facility's capability to convert $\mathrm{UF}_{6}$ to $\mathrm{UO}_{2}$. Section 2 also includes information about the $\mathrm{UF}_{6}$-to- $\mathrm{UO}_{2}$ conversion capability of a pilot plant constructed at the Honeywell International Metropolis Works for research purposes in cooperation with DOE. The capabilities of foreign fuel fabrication plants to convert $\mathrm{UF}_{6}$ to uranium oxide are described to the extent information could be found. Section 3 discusses transportation

considerations. Section 4 discusses relevant regulatory considerations, and Section 5 provides analysis and conclusions. 


\section{CHARACTERIZATION OF COMMERCIAL NUCLEAR FUEL FABRICATION FACILITIES}

\subsection{OVERVIEW OF U.S. FACILITIES}

Table 1 summarizes information about the $\mathrm{UF}_{6}$-to- $\mathrm{UO}_{2}$ conversion capabilities of fuel fabrication facilities in the United States. The table also includes information about a pilot plant located at the Honeywell International Metropolis Works in Metropolis, Illinois. While the Metropolis Works does not currently operate a $\mathrm{UF}_{6}$-to- $\mathrm{UO}_{2}$ conversion process, in 1997 a pilot plant jointly funded by DOE and the facility's owner was constructed there to demonstrate a technology for converting natural $\mathrm{UF}_{6}$ to $\mathrm{U}_{3} \mathrm{O}_{8}$ and $\mathrm{UO}_{2}$. Hence, because of DOE's prior involvement with the project, it seemed appropriate to report any potential conversion capacity that facility might provide.

Sections 2.1.1 through 2.1.8 provide more detailed discussions for each facility, including corporate ownership information, facility description, facility address, currently operating capacity, and capacity potentially available to DOE. The results of informal telephone interviews conducted during January 2001 with representatives at most of the U.S. fuel fabrication facilities are reported in the Appendix.

\subsubsection{Westinghouse Electric Company LLC - Columbia Fuel Fabrication Facility}

Corporate Ownership: Westinghouse Electric Company LLC (WEC) is 100\% owned by BNFL Nuclear Services Inc., which is a wholly owned subsidiary of BNFL plc.

Facility Description: The Columbia Fuel Fabrication Facility (CFFF) is primarily engaged in the manufacture of fuel assemblies for commercial nuclear reactors. The CFFF holds a license from the U.S. Nuclear Regulatory Commission (NRC) (SNM-1107; Docket No. 70-1151) authorizing, among others, the following activities:

- Receipt of low-enriched (less than or equal to $5.0 \%$ by weight [wt $\%$ ]) uranium-235 (U-235) in the form of $\mathrm{UF}_{6}$;

- Conversion of $\mathrm{UF}_{6}$ to $\mathrm{UO}_{2}$ powder; and

- Processing of $\mathrm{UO}_{2}$ through pellet pressing and sintering, fuel rod loading and sealing, and fuel assembly fabrication. 
TABLE 1 Summary of $\mathrm{UF}_{6}$-to-UO ${ }_{2}$ Conversion Capabilities at U.S. Fuel Fabrication Facilities and the Metropolis Works Pilot Plant

\begin{tabular}{|c|c|c|c|}
\hline Facility & Location & $\begin{array}{c}\text { Capability to Convert } \\
\mathrm{UF}_{6} \text { to } \mathrm{UO}_{2}\end{array}$ & $\begin{array}{l}\text { Capacity Potentially } \\
\text { Available to DOE }\end{array}$ \\
\hline $\begin{array}{l}\text { Westinghouse Electric Company } \\
\text { LLC - Columbia Fuel Fabrication } \\
\text { Facility }\end{array}$ & $\begin{array}{l}\text { Columbia, South } \\
\text { Carolina }\end{array}$ & $\begin{array}{l}\text { Current operating } \\
\text { capacity }=1,150 \mathrm{tHM} / \mathrm{a} \\
\left(1,700 \mathrm{tUF}_{6} / \mathrm{a}\right) .\end{array}$ & $\begin{array}{l}\text { Unknown. } \\
\text { Westinghouse Electric } \\
\text { Company did not } \\
\text { respond to phone } \\
\text { messages. }\end{array}$ \\
\hline $\begin{array}{l}\text { BWX Technologies, Inc. - Naval } \\
\text { Nuclear Fuel Division }\end{array}$ & $\begin{array}{l}\text { Lynchburg, } \\
\text { Virginia }\end{array}$ & $\begin{array}{l}\text { No existing } \mathrm{UF}_{6} \\
\text { conversion capability. }\end{array}$ & None. \\
\hline $\begin{array}{l}\text { CE Nuclear Power LLC - } \\
\text { Hematite Fuel Manufacturing } \\
\text { Operations }\end{array}$ & $\begin{array}{l}\text { Hematite, } \\
\text { Missouri }\end{array}$ & $\begin{array}{l}\text { Current operating } \\
\text { capacity }=450 \text { tHM/a } \\
\left(666 \mathrm{tUF}_{6} / \mathrm{a}\right) \text {; operations } \\
\text { to be discontinued after } \\
2001 .\end{array}$ & None. \\
\hline $\begin{array}{l}\text { Framatome ANP Richland } \\
\text { Division, Inc. (formerly Siemens } \\
\text { Power Corp.) - Engineering and } \\
\text { Manufacturing Facility }\end{array}$ & $\begin{array}{l}\text { Richland, } \\
\text { Washington }\end{array}$ & $\begin{array}{l}\text { Approx. current } \\
\text { operating capacity = } \\
700 \mathrm{tHM} / \mathrm{a} \\
\left(1,035 \mathrm{tUF}_{6} / \mathrm{a}\right) .\end{array}$ & $\begin{array}{l}\text { Possibly } 300 \mathrm{tUF}_{6} / \mathrm{a} \text {. } \\
\text { This is capacity } \\
\text { currently reserved for } \\
\text { unexpected orders. }\end{array}$ \\
\hline $\begin{array}{l}\text { Framatome ANP, Inc. (formerly } \\
\text { Framatome Cogema Fuels) - } \\
\text { Lynchburg Manufacturing Facility }\end{array}$ & $\begin{array}{l}\text { Lynchburg, } \\
\text { Virginia }\end{array}$ & $\begin{array}{l}\text { Fuel assembly only; } \\
\text { no existing } \mathrm{UF}_{6} \\
\text { conversion capability. }\end{array}$ & None. \\
\hline $\begin{array}{l}\text { Global Nuclear Fuel - Americas, } \\
\text { LLC }\end{array}$ & $\begin{array}{l}\text { Wilmington, } \\
\text { North Carolina }\end{array}$ & $\begin{array}{l}\text { Current operating } \\
\text { capacity }=1,200 \mathrm{tHM} / \mathrm{a} \\
\left(1,775 \mathrm{tUF}_{6} / \mathrm{a}\right) .\end{array}$ & None. \\
\hline $\begin{array}{l}\text { Nuclear Fuel Services - Erwin } \\
\text { Facility }\end{array}$ & $\begin{array}{l}\text { Erwin, } \\
\text { Tennessee }\end{array}$ & $\begin{array}{l}\text { No existing low-enriched } \\
\text { uranium conversion } \\
\text { capability. }\end{array}$ & $\begin{array}{l}\text { Negotiable; } \\
\text { modification of } \\
\text { equipment and facilities } \\
\text { would be required. }\end{array}$ \\
\hline $\begin{array}{l}\text { Honeywell International, } \\
\text { Metropolis Works }\end{array}$ & $\begin{array}{l}\text { Metropolis, } \\
\text { Illinois }\end{array}$ & $\begin{array}{l}\text { Pilot plant is currently } \\
\text { shut down, but could be } \\
\text { reactivated; estimated } \\
\text { capacity of pilot plant, if } \\
\text { operating = } 300 \text { to } \\
400 \text { tons (U.S.) ( } 270 \text { to } \\
360 \text { metric tons) of } \\
\mathrm{UF}_{6} / \text { a. }\end{array}$ & $\begin{array}{l}\text { Unknown. } \\
\text { Converdyn did not } \\
\text { respond to phone } \\
\text { messages. }\end{array}$ \\
\hline
\end{tabular}


In addition, the license authorizes the CFFF to possess, among other things, the following materials, which are possibly relevant to conversion of the depleted $\mathrm{UF}_{6}$ inventory:

- No more than $5 \mathrm{~g}$ of plutonium in feedstock containing transuranics and fission products.

- No more than 75,000 kg of U-235 in any chemical and/or physical form of uranium (except metal) that has been enriched to no more than $5 \mathrm{wt} \%$.

Two processes are installed at the CFFF for converting $\mathrm{UF}_{6}$ to $\mathrm{UO}_{2}$ powder: the ammonium diuranate $(\mathrm{ADU})$ process and the integrated dry route process. However, the integrated dry route process has been mothballed.

Facility Address:

Currently Operating Capacity:

Capacity Potentially Available to DOE:
Commercial Nuclear Fuel Division

Westinghouse Electric Company LLC

Drawer R

Columbia, SC 29250

1,150 metric tons heavy metal per annum (tHM/a)

$\left(1,700 \mathrm{tUF}_{6} / \mathrm{a}\right)$

Unknown; Westinghouse Electric Company did not respond to phone messages.

\subsubsection{BWX Technologies, Inc. - Naval Nuclear Fuel Division}

Corporate Ownership: BWX Technologies, Inc. (BWXT) is a wholly owned subsidiary of Babcock \& Wilcox Investment Company, Inc., which is a wholly owned subsidiary of McDermott Incorporated, which is a wholly owned subsidiary of McDermott International, Inc.

Facility Description: The BWXT, Naval Nuclear Fuel Division (NNFD), is located in Campbell County, Virginia, on an oxbow of the James River, approximately 5 miles east of Lynchburg, Virginia. The primary mission of the NNFD has been fuel fabrication for the naval reactor program, research and university reactor programs, and compact reactors. In addition, the NNFD purifies highly enriched uranium (HEU) and recovers uranium from scrap fuel and manufacturing waste streams. 
The NNFD holds a license from the NRC (SNM-42; Docket No. 70-27) authorizing, among others, the following activities at the NNFD site:

- Fabrication of nuclear fuel and components for the naval reactor program, research and university reactor programs, and compact reactors;

- Recovery/disposal of scrap fuel generated by NNFD and other organizations, including irradiated fuel;

- Enrichment adjustment operations of authorized material; and

- Receipt and cleaning (to recover uranium from the $\mathrm{UF}_{6}$ heels) of $\mathrm{UF}_{6}$ shipping containers that have been exhausted of $\mathrm{UF}_{6}$ prior to receipt.

In addition, the license authorizes the NNFD to possess the following materials, which are possibly relevant to conversion of the depleted $\mathrm{UF}_{6}$ inventory:

- No more than $80,000 \mathrm{~kg}$ of U-235 contained in uranium having any enrichment or form (except $\mathrm{UF}_{6}$ );

- Less than $1,000 \mathrm{~kg}$ of $\mathrm{UF}_{6}$ having any enrichment, provided that no container contains more than $50 \mathrm{~kg}$ of $\mathrm{UF}_{6}$;

- No more than $200,000 \mathrm{~kg}$ of source material (e.g., natural uranium) in any chemical and/or physical form; and

- No more than $20 \mathrm{mCi}$ each of fission products and transuranium elements in any physical and/or chemical form, provided that the total does not exceed $100 \mathrm{mCi}$.

Conversion of $\mathrm{UF}_{6}$ to $\mathrm{UO}_{2}$ is not an activity specifically authorized by the NNFD's NRC license, and the facility currently has no capability to convert $\mathrm{UF}_{6}$ to $\mathrm{UO}_{2}$.

Facility Address:

BWX Technologies, Inc.

Naval Nuclear Fuel Division

P.O. Box 785

Lynchburg, VA 24505-0785

Currently Operating Capacity: None; facility has no process capability to convert $\mathrm{UF}_{6}$ to $\mathrm{UO}_{2}$. 
Capacity Potentially Available to DOE: None.

\subsubsection{CE Nuclear Power LLC - Hematite Fuel Manufacturing Operations}

Corporate Ownership: CE Nuclear Power LLC is a wholly owned subsidiary of Westinghouse Electric Company LLC, which is a wholly owned subsidiary of BNFL Nuclear Services Inc., which is a wholly owned subsidiary of BNFL plc.

Facility Description: The Hematite Fuel Manufacturing Operations is currently scaling down with the goal of discontinuing manufacturing operations by the end of 2001 (WEC 2000a).

Facility Address:

3300 State Road P

Festus, MO 63028

Currently Operating Capacity: $\quad 450$ tHM/a $\left(666 \mathrm{tUF}_{6} / \mathrm{a}\right)$

Capacity Potentially Available to DOE: None; facility operations scheduled to discontinue by the end of 2001 .

\subsubsection{Framatome ANP Richland, Inc. - Engineering and Manufacturing Facility}

Corporate Ownership: Effective Thursday, February 1, 2001, Siemens Power Corporation (SPC), the owner/operator of the nuclear fuel Engineering and Manufacturing Facility located at 2101 Horn Rapids Road, Richland, Washington, changed its name to Framatome Advanced Nuclear Power (ANP) Richland, Inc. The name change coincided with the signing in Europe of the closing documents for the merger of the worldwide nuclear business of the former SPC's parent company, Siemens AG, with that of the French company, Framatome S.A. The resulting joint venture company, Framatome ANP SAS, exists retroactive to January 1, 2001 (Maas 2001).

Effective March 19, 2001, the stock of Framatome ANP Richland, Inc., was transferred to Framatome ANP, Inc., headquartered in Lynchburg, Virginia. Framatome ANP, Inc., in turn is owned by Framatome ANP SAS. In addition to owning the Richland facility, Framatome ANP, Inc., owns the former Framatome Cogema Fuels (FCF) nuclear fuel fabrication plant in Lynchburg, Virginia (Maas 2001).

Facility Description: The Engineering and Manufacturing Facility is located 0.9 miles west of the intersection of Stevens Drive and Horn Rapids Road within the north boundary of the city of Richland, Washington. Uranium is processed primarily within the dry conversion, $\mathrm{UO}_{2}$, and Specialty Fuels Buildings. Storage of $\mathrm{UF}_{6}$ cylinders is conducted outside, and packaged fuel elements or other uranium products are stored outside or in a warehouse while awaiting shipment. 
The Engineering and Manufacturing Facility holds a license from the NRC (SNM-1227; Docket No. 70-1257) that allows for the possession of no more than 25,000 kg of U-235 in uranium compounds that have been enriched to no more than $5 \mathrm{wt} \%$. The license authorizes, among others, the following activities:

- Manufacturing of nuclear fuel, including all operational steps from $\mathrm{UF}_{6}$ to $\mathrm{UO}_{2}$ conversion through packaging finished fuel elements; uranium compounds up to $5 \mathrm{wt} \% \mathrm{U}-235$;

- All operational steps of dry $\mathrm{UF}_{6}-$ to- $\mathrm{UO}_{2}$ conversion and $\mathrm{UO}_{2}$ powder preparation; uranium compounds up to $5 \mathrm{wt} \% \mathrm{U}-235$;

- Storage of a planar array of closed containers of uranium oxide (up to $5 \mathrm{wt} \%$ U-235) pellets that are externally free of significant contamination;

- Unloading from shipping containers and storage of containers of uranium compounds up to $5 \mathrm{wt} \%$ U-235 (product, scrap and waste materials);

- Loading into shipping containers and storage of containers of uranium compounds up to $5 \mathrm{wt} \%$ U-235 (product, scrap, and waste materials);

- $\quad$ Outside storage of $\mathrm{UF}_{6}$ cylinders (full and empty); $\mathrm{UF}_{6}$ up to $5 \mathrm{wt} \% \mathrm{U}-235$;

- Outside storage of fuel $\left(\mathrm{UO}_{2}\right.$ up to $\left.5 \mathrm{wt} \% \mathrm{U}-235\right)$ packed for shipment; the transport containers are closed, sealed, and properly labeled for shipment; and

- $\mathrm{UF}_{6}$ (solid and in waste solution up to $5 \mathrm{wt} \% \mathrm{U}-235$ ) cylinder recertification activities.

In addition, Framatome ANP Richland's State of Washington Radioactive Materials License (WN-I062-1) authorizes the Engineering and Manufacturing Facility to possess the following materials, which are possibly relevant to conversion of the depleted $\mathrm{UF}_{6}$ inventory:

- No more than $85,000 \mathrm{~kg}$ of source material (includes natural and depleted uranium). 
In July 2000, Siemens Power Corporation received approval of an amendment to the Engineering and Manufacturing Facility's NRC license to allow receipt, processing, storage, and shipping of uranium containing plutonium and other transuranic isotopes as follows (Maas 2001):

- The concentration of transuranic isotopes (i.e., the alpha activity of plutonium and neptunium) in reprocessed uranium shall be limited to less than $50 \mathrm{~Bq} / \mathrm{g}$ $\mathrm{U}$ or, for uranium enriched to less than $2.18 \% \mathrm{U}-235$, to a lesser value which assures that the limit of 1 microgram of plutonium per gram of U-235 (: $\mathrm{g} \mathrm{Pu} / \mathrm{g} \mathrm{U}-235)$ is not exceeded.

Before the merger of Siemens AG and Framatome S.A., Siemens Power Corporation advised the NRC that all licensed activities at the Engineering and Manufacturing Facility would continue without interruption after the merger, and that there are no planned changes in the operational organization, location, facilities, equipment or procedures associated with the facility's license (Siemens 2000).

Facility Address:

Currently Operating Capacity:

Capacity Potentially Available to DOE: $\quad$ Possibly $300 \mathrm{tUF}_{6} / \mathrm{a}$
Framatome ANP Richland

2101 Horn Rapids Road

Richland, WA 99352-0130

$700 \mathrm{tHM} / \mathrm{a}\left(1,035 \mathrm{tUF}_{6} / \mathrm{a}\right)$

\subsubsection{Framatome ANP, Inc. - Lynchburg Manufacturing Facility}

Corporate Ownership: In anticipation of the merger of the worldwide nuclear business of Framatome S.A. with the worldwide nuclear business of Siemens AG, Framatome Cogema Fuels merged into Framatome Technologies Group, Inc., which now has become Framatome ANP, Inc. (a Delaware corporation). Framatome ANP, Inc., is a wholly owned subsidiary of Framatome USA, which is a wholly owned subsidiary of Framatome ANP SAS (a French corporation).

Facility Description: The Lynchburg Manufacturing Facility is located in Campbell County, Virginia, on State Route 726. The facility primarily manufactures fuel assemblies for use in commercial pressurized water nuclear reactors. The facility holds a license from the NRC (SNM1168; Docket No. 70-1201), authorizing the following activities, among others:

- Receipt of $\mathrm{UO}_{2}$ pellets;

- Receipt of sealed fuel rods and fuel assemblies; 
- Loading of $\mathrm{UO}_{2}$ pellets into fuel rods;

- Fabrication of fuel rods into fuel assemblies;

- Downloading of $\mathrm{UO}_{2}$ fuel pellets from incoming fuel rods and assemblies; and

- Shipping of products, scrap, or waste for off-site disposition.

The NRC license also authorizes the Lynchburg Manufacturing Facility to receive, acquire, possess, and transfer the following materials, which are relevant to conversion of the depleted $\mathrm{UF}_{6}$ inventory:

- No more than $15,000 \mathrm{~kg}$ of U-235 in the form of oxide pellets composed of uranium enriched up to $5.1 \mathrm{wt} \% \mathrm{U}-235$ (and enriched processed uranium containing plutonium and other transuranic isotopes);

- No more than $100,000 \mathrm{~kg}$ of natural or depleted uranium in the form of oxide pellets or powder; and

- Less than $1,000 \mathrm{~kg}$ of natural $\mathrm{UF}_{6}$, with no container exceeding $50 \mathrm{~kg}$.

Uranium conversion from any form to another form is not an activity authorized by the Lynchburg Manufacturing Facility's NRC license, and the facility has no capability to conduct such conversion.

Facility Address:

3315 Old Forest Road

Lynchburg, VA 24506-0935

Currently Operating Capacity: $\quad$ None; facility conducts only fuel component assembly.

Capacity Potentially Available to DOE: None; facility has no $\mathrm{UF}_{6}$-to- $\mathrm{UO}_{2}$ conversion capability.

\subsubsection{Global Nuclear Fuel - Americas, LLC}

Corporate Ownership: Global Nuclear Fuel - Americas LLC is a wholly owned subsidiary of Global Nuclear Fuel Holding Co., LLC, which is a joint venture of General Electric (GE) Company, Toshiba, and Hitachi, with General Electric holding the majority ownership interest. 
Facility Description: The Global Nuclear Fuel - Americas, LLC facility (GNF-A) is located on U.S. Highway 117 approximately 6 miles north of Wilmington, North Carolina. The following major facilities are situated on the GNF-A property:

- The GE Aircraft Engine facility, which is not involved in the nuclear fuel manufacturing operation;

- The GE Services Components Operation facility, where nonradioactive reactor components are manufactured;

- The Fuel Components Operation facility, where nonradioactive components for reactor fuel assemblies are manufactured; and

- The fuels complex containing the fuel manufacturing facility, which includes the Fuel Manufacturing Operation and Dry Conversion Process buildings and supporting facilities.

The GNF-A holds a license from the NRC (SNM-1097; Docket No. 70-1113) authorizing it to conduct the following activities, among others:

- Conversion of $\mathrm{UF}_{6}$ to uranium oxides by the ADU process and the dry conversion process;

- Operation of process technology for the purpose of converting $\mathrm{UF}_{6}$ to $\mathrm{UO}_{2}$ and other intermediate compounds by chemical and dry processes;

- Storage of unirradiated fuel assemblies and uranium compounds and mixtures in areas arranged specifically for maintenance of criticality and radiological safety;

- Design, fabrication, and testing of uranium prototype processing equipment; and

- Maintenance and repair of uranium processing equipment and auxiliary systems.

The NRC license also authorizes receipt, acquisition, possession, use in the specified manner, and transfer of the following materials, which are relevant to conversion of the depleted $\mathrm{UF}_{6}$ inventory:

- No more than 50,000 kg U-235 contained in uranium (in any chemical and/or physical form) enriched to no more than $5 \mathrm{wt} \% \mathrm{U}-235$. 
Facility Address:

Currently Operating Capacity:

Capacity Potentially Available to DOE:
3901 Castle Hayne Road

Wilmington, NC 28401

$1,200 \mathrm{tHM} / \mathrm{a}\left(1,775 \mathrm{t} \mathrm{UF}_{6} / \mathrm{a}\right)$

None; Global Nuclear Fuel - Americas stated that the company is not interested in converting depleted $\mathrm{UF}_{6}$ at this facility.

\subsubsection{Nuclear Fuel Services, Inc. - Erwin Facility}

Corporate Ownership: Nuclear Fuel Services, Inc.

Facility Description: The Nuclear Fuel Services, Inc. (NFS) facility is located on Banner Hill Road in Erwin, Tennessee. Current process work at the facility includes production of nonirradiated nuclear fuel and other products from both low- and high-enriched uranium. The NFS facility holds a license from the NRC (SNM-124; Docket No. 70-143), which authorizes the following activities, in addition to the manufacture of highly enriched uranium fuel:

- Recovery of low and highly enriched uranium from uranium materials having any enrichment, chemical composition, and physical form (except pyrophoric). This activity includes washing of $\mathrm{UF}_{6}$ cylinders and recovery of $\mathrm{UF}_{6}$ heels.

- Downblending of highly enriched, liquid uranyl nitrate to low-enriched uranyl nitrate.

- Conversion of low and highly enriched uranyl nitrate to uranium oxide.

- Laboratory operations for manufacturing.

- Research and development.

- Waste treatment and packaging for shipment.

The NRC license also authorizes the NFS facility to possess the following materials, which are possibly relevant to conversion of the depleted $\mathrm{UF}_{6}$ inventory:

- No more than 7,000 kg U-235 in uranium enriched up to $100 \mathrm{wt} \%$. This uranium may contain as contaminants up to $1 \times 10^{-6}$ grams of plutonium per 
gram of uranium, 0.25 millicuries $(\mathrm{mCi})$ of fission products per gram of uranium, and $1.5 \times 10^{-5}$ grams of transuranic materials (including plutonium) per gram of uranium.

NFS has an installed line for converting high-enriched $\mathrm{UF}_{6}$ to $\mathrm{UO}_{2}$, but it is not currently operating. Significant licensing activity would be required to permit operations. No low-enriched $\mathrm{UF}_{6}$-to-UO $\mathrm{UO}_{2}$ capability currently exists, although NFS has produced ton quantities of low-enriched $\mathrm{UO}_{2}$ in the past. Conversion of $\mathrm{UF}_{6}$ to $\mathrm{UO}_{2}$ is not an activity specifically authorized by the NFS facility's NRC license.

Facility Address:

Currently Operating Capacity:

Capacity Potentially Available to DOE:
1205 Banner Hill Road

Erwin, TN 37650

None; facility has no existing low-enriched $\mathrm{UF}_{6}$ conversion capability.

Negotiable; Nuclear Fuel Services, Inc., is interested in converting depleted $\mathrm{UF}_{6}$ at this facility, but modification of equipment and facilities would be required.

\subsubsection{Honeywell International - Metropolis Works}

Corporate Ownership: Honeywell International, Inc. [Note: Converdyn, a general partnership between affiliates of Honeywell and General Atomics, is the exclusive agent for conversion sales from the Metropolis Works. Also, on November 30, 2000, Honeywell International and General Electric Company requested the NRC's consent for the proposed indirect transfer of ownership and control of the Metropolis Works from Honeywell International to General Electric Company. However, completion of the transfer of ownership and control has been delayed pending resolution of an in depth probe by the European Commission (Chicago Tribune 2001).]

Facility Description: The Metropolis Works, located near Metropolis, Illinois, converts natural $\mathrm{U}_{3} \mathrm{O}_{8}$ to $\mathrm{UF}_{6}$. The plant has no full-scale capacity to convert $\mathrm{UF}_{6}$ to uranium oxide. However, in 1997, DOE entered into an agreement with the owners of the Metropolis Works (then Allied Signal, Inc. and General Atomics) to fund $50 \%$ of the cost of a pilot plant as a demonstration of a proposed dry process (patented by General Atomics) for converting $\mathrm{UF}_{6}$ into $\mathrm{U}_{3} \mathrm{O}_{8}$ or $\mathrm{UO}_{2}$ and anhydrous hydrofluoric acid. The pilot plant was constructed at the Metropolis Works, and test runs were conducted with $\mathrm{UF}_{6}$ feed between early February and July 1998. The program was considered successful in that $\mathrm{UF}_{6}$ was successfully converted to uranium oxide, and anhydrous hydrofluoric acid was recovered and successfully recycled in the main conversion plant at the site. Upon completion 
of the program, the pilot plant was secured, emptied, flushed, cleaned, and otherwise mothballed. The capacity of the pilot plant, if it were operational, was estimated at 300 to 400 tons (U.S.) UF $/$ a.

The Metropolis Works holds a license from the NRC (SUB-526; Docket No. 40-3392), which authorizes, among other things, operation of the pilot plant. The NRC license also authorizes the Metropolis Works to possess the following materials that are relevant to conversion of the depleted $\mathrm{UF}_{6}$ inventory:

- No more than 68 million $\mathrm{kg}$ of natural uranium in the following forms: $\mathrm{U}_{3} \mathrm{O}_{8}$, $\mathrm{UO}_{2}, \mathrm{UO}_{3}, \mathrm{UF}_{4}$, and $\mathrm{UF}_{6}$.
Facility Address:
P.O. Box 430
Metropolis, IL 62960
Currently Operating Capacity:
None; facility has been mothballed.
Capacity Potentially Available to DOE: Unknown; Converdyn, the exclusive agent for conversion sales from the Metropolis Works, did not respond to phone messages.

\subsection{OVERVIEW OF NON-U.S. FACILITIES}

Table 2 summarizes information about the $\mathrm{UF}_{6}$-to- $\mathrm{UO}_{2}$ conversion capabilities of fuel fabrication facilities in other countries. Sections 2.2.1 through 2.2.8 provide more details (to the extent available). No attempt was made for this report to contact these non-U.S. facilities.

\subsubsection{France}

France hosts the COGEMA W Plant, which is not a fuel fabrication facility, but which converts depleted $\mathrm{UF}_{6}$ to $\mathrm{U}_{3} \mathrm{O}_{8}$. This plant has a design capacity of approximately 20,000 tons of uranium per year (tU/a) (IAEA 2001a).

Contact Address:

Cogema Pierrelatte B.P.

1626700 Pierrelatte Cedex

France 
TABLE 2 Summary of $\mathrm{UF}_{6}$-to-UO ${ }_{2}$ Conversion Capabilities at Non-U.S. Fuel Fabrication Facilities

\begin{tabular}{|c|c|c|}
\hline Facility & Location & $\begin{array}{l}\text { Capability to Convert } \\
\mathrm{UF}_{6} \text { to } \mathrm{UO}_{2}\end{array}$ \\
\hline COGEMA - W Plant & France & $\begin{array}{l}\text { This plant, which is not a fuel fabrication facility, } \\
\text { converts depleted } \mathrm{UF}_{6} \text { to depleted } \mathrm{U}_{3} \mathrm{O}_{8} \text {; approx. } \\
\text { capacity }=20,000 \mathrm{tU} / \mathrm{a}\left(29,600 \mathrm{tUF}_{6} / \mathrm{a}\right)\end{array}$ \\
\hline BNFL plc - Springfields Works & United Kingdom & $\begin{array}{l}\text { Dry conversion process; approx. capacity }= \\
550 \mathrm{tHM} / \mathrm{a}\left(813 \mathrm{tUF}_{6} / \mathrm{a}\right) \text {. }\end{array}$ \\
\hline $\begin{array}{l}\text { Mitsubishi Nuclear Fuel Co., Ltd. } \\
\text { - Tokai-mura }\end{array}$ & Japan & $\begin{array}{l}\mathrm{UF}_{6} \text { to } \mathrm{UO}_{2} \text { conversion process could not be } \\
\text { identified; approx. capacity }=450 \mathrm{tU} / \mathrm{a}\left(665 \mathrm{tUF}_{6} / \mathrm{a}\right) .\end{array}$ \\
\hline $\begin{array}{l}\text { Advanced Nuclear Fuels } \mathrm{GmbH}- \\
\text { Lingen Facility }\end{array}$ & Germany & $\begin{array}{l}\text { Dry conversion process; approx. capacity }=400 \mathrm{tU} / \mathrm{a} \\
\left(592 \mathrm{tUF}_{6} / \mathrm{a}\right) .\end{array}$ \\
\hline FBFC - Dessel Plant & Belgium & $\begin{array}{l}\mathrm{UF}_{6} \text { to } \mathrm{UO}_{2} \text { conversion process could not be } \\
\text { identified; approx. capacity }=500 \mathrm{tHM} / \mathrm{a} \\
\left(740 \mathrm{tUF}_{6} / \mathrm{a}\right) \text {. }\end{array}$ \\
\hline $\begin{array}{l}\text { Westinghouse Atom - Nuclear } \\
\text { Fuel Factory }\end{array}$ & Sweden & $\begin{array}{l}\mathrm{UF}_{6} \text { to } \mathrm{UO}_{2} \text { conversion process could not be } \\
\text { identified; approx. capacity }=600 \mathrm{tHM} / \mathrm{a} \\
\left(887 \mathrm{tUF}_{6} / \mathrm{a}\right) .\end{array}$ \\
\hline $\begin{array}{l}\text { Korea Nuclear Fuel Co., Ltd. - } \\
\text { Taejon }\end{array}$ & Korea & $\begin{array}{l}\text { Dry conversion process; approx. capacity }= \\
400 \mathrm{tHM} / \mathrm{a}\left(592 \mathrm{tUF}_{6} / \mathrm{a}\right) .\end{array}$ \\
\hline $\begin{array}{l}\text { Industrias Nucleares do Brasil } \\
\text { (INB) - Resende Unit } 2\end{array}$ & Brazil & $\begin{array}{l}\text { AUC }\left(\mathrm{CO}_{2}-\mathrm{NH}_{3}\right) \text { process; approx. capacity }= \\
160 \mathrm{tHM} / \mathrm{a}\left(237 \mathrm{tUF}_{6} / \mathrm{a}\right) .\end{array}$ \\
\hline
\end{tabular}

\subsubsection{United Kingdom}

The United Kingdom hosts one light water reactor fuel fabrication plant: the Springfields Works. This facility is owned and operated by BNFL plc. It converts $\mathrm{UF}_{6}$ to $\mathrm{UO}_{2}$ powder, produces pellets from the $\mathrm{UO}_{2}$ powder, and fabricates fuel rods and assemblies from the $\mathrm{UO}_{2}$ pellets. The Springfields Works fuel fabrication plant currently has an operating $\mathrm{UF}_{6}$-to- $\mathrm{UO}_{2}$ conversion capacity of approximately $550 \mathrm{tHM} / \mathrm{a}$ (IAEA 2001b).

Contact Address:
British Nuclear Fuels plc

Springfields Works

Salwick, Preston

Lancashire PR4 OXJ

United Kingdom 


\title{
2.2.3 Japan
}

One nuclear fuel manufacturing facility in Japan converts $\mathrm{UF}_{6}$ to $\mathrm{UO}_{2}$. Mitsubishi Nuclear Fuel Co., Ltd. operates this plant, which has a currently operating conversion capacity of 450 tU/a. (IAEA 2001c).

Contact Address:

Mitsubishi Nuclear Fuel Co., Ltd.

622-1 Funaishikawa, Tokai-mura, Naka-gun, Ibaraki Prefecture, Japan 319-1197

\subsubsection{Germany}

In Germany, Advanced Nuclear Fuels GmbH, a subsidiary of Siemens AG, operates the Lingen facility, which fabricates nuclear fuel for light water reactors by converting $\mathrm{UF}_{6}$ to $\mathrm{UO}_{2}$ using the dry conversion process, pressing and sintering the $\mathrm{UO}_{2}$ powder into pellets, sealing the pellets in fuel rods, and assembling the rods into fuel elements. This plant has a conversion capacity of approximately $400 \mathrm{tU} / \mathrm{a}$. However, the fuel production capacity is $650 \mathrm{tHM} / \mathrm{a}$, which is achieved by receiving some $\mathrm{UO}_{2}$ from off-site (ANF 2000).

\section{Contact Address:}

\author{
Advanced Nuclear Fuels GmbH \\ Am Seitenkanal 1 \\ 49811 Lingen \\ Germany
}

\subsubsection{Belgium}

Belgium hosts the FBFC International nuclear fuel fabrication plant at Dessel. This plant handles fuel fabrication operations, ranging from conversion of $\mathrm{UF}_{6}$ to $\mathrm{UO}_{2}$ powder through delivery of completed fuel assemblies. It has an output capacity of approximately 500 tHM/a (IAEA 2001d).

Contact Address:

FBFC International SA

Europalaan 12

B-2480 Dessel

Belgium 


\subsubsection{Sweden}

The Nuclear Fuel Operations of Westinghouse Atom manufacture light-water reactor fuel at the Nuclear Fuel Factory situated in the city of Vasteras, Sweden. This facility was formerly owned by Asea Brown Boveri (ABB), whose commercial nuclear power businesses were acquired by BNFL's Westinghouse Electric Company in May 2000 (WEC 2000b). The Nuclear Fuel Factory has an output capacity of $400 \mathrm{tHM} / \mathrm{a}$. The $\mathrm{UF}_{6}$-to- $\mathrm{UO}_{2}$ conversion capacity is limited to $600 \mathrm{tHM} / \mathrm{a}$ (WEC 2000c).

Contact Address: $\quad$ Westinghouse Atom

SE-721 63 Västerås

Sweden

\subsubsection{Korea}

In Korea, the Korea Nuclear Fuel Company, Ltd. (KNFC) operates a fabrication facility for pressurized-water reactor (PWR) fuel. It has the capacity to produce $400 \mathrm{tHM} / \mathrm{a}$ (KNFC 2000a). This facility, located at Taejeon, was modified in 1998 by replacing the ammonium uranyl carbonate (AUC) process with the dry conversion process for converting $\mathrm{UF}_{6}$ to $\mathrm{UO}_{2}(\mathrm{KNFC} 2000 \mathrm{~b})$.

\section{Contact Address:}

Korea Nuclear Fuel Company, Ltd.

150 Deogjin-Dong, Yusong-ku

Taejeon City, Republic of Korea

\subsubsection{Brazil}

In Brazil, Industrias Nucleares do Brasil (INB) operates the Resende plant, which consists of two separate units. Unit 1 is a fuel assembly production line. Unit 2, which began operations during 2000, is a chemical processing facility that accepts enriched $\mathrm{UF}_{6}$, converts it to $\mathrm{UO}_{2}$, and processes the $\mathrm{UO}_{2}$ into pellets. This conversion plant is based on the $\mathrm{AUC}\left(\mathrm{CO}_{2}-\mathrm{NH}_{3}\right)$ process and has a capacity of $160 \mathrm{tHM} / \mathrm{a}$ (IAEA 2001e).

Contact Address:

Industrias Nucleares do Brasil (INB)

Av. Presidente Wilson 231

9-11 Pav., Centro, CEP 20.030-021

Rio de Janeiro, Brazil 


\subsubsection{Other Countries}

In addition to the fuel fabrication facilities described in Sections 2.2.1 through 2.2.8, the countries of Spain, China, India, Kazakhstan, and Russia have been reported to host nuclear fuel fabrication facilities. However, information could not be located to verify that the fuel fabrication plants in these countries are capable of converting $\mathrm{UF}_{6}$ to $\mathrm{UO}_{2}$. 


\section{TRANSPORTATION}

The use of commercial fuel fabrication facilities to convert depleted $\mathrm{UF}_{6}$ would require the off-site shipment of some or all of the depleted $\mathrm{UF}_{6}$ cylinders stored at East Tennessee Technology Part (ETTP) (formerly the Oak Ridge K-25 site), Portsmouth, and Paducah. Shipments could be made by legal-weight truck to all commercial facilities. Also, it is possible that shipments could be made by rail if the commercial facilities have rail access on-site or nearby. Because railcars have larger payload capacity than truck trailers, transportation by rail could significantly reduce the total number of shipments required. However, a full investigation of the transportation infrastructure available at the commercial facilities was beyond the scope of this report.

Commercial fuel fabricators typically receive $\mathrm{UF}_{6}$ in $30 \mathrm{~B}$ cylinders. A $30 \mathrm{~B}$ cylinder has a 30 -inch diameter and a loaded weight of slightly less than 3 metric tons. In comparison, depleted $\mathrm{UF}_{6}$ is stored and would be shipped primarily in 48-inch-diameter cylinders with a gross weight of approximately 14 metric tons. Consequently, it is likely that commercial facilities would have to upgrade or modify their shipping and receiving facilities (such as fixed or mobile cranes) before depleted $\mathrm{UF}_{6}$ shipments could be received.

In general, the distance over which depleted $\mathrm{UF}_{6}$ cylinders are shipped is a primary factor in determining both the cost and the risk associated with a shipment. Federal regulations do not place route restrictions on the movement of depleted $\mathrm{UF}_{6}$ on U.S. highways or railroads. For purposes of comparison for this report, representative shipment routes from the three current storage sites to commercial facilities were generated with standard route prediction models. Representative shipment routes were identified by using the Transportation Routing Analysis Geographic Information System (WebTragis) (Johnson and Michelhaugh 2000). The routes were selected to be reasonable and consistent with routing regulations and general practice, but are considered representative because the actual routes to be used would likely be chosen by the shipper.

The results of route predictions for both truck and rail shipment modes are summarized in Table 3. Considering all origins and destinations, truck route lengths would range from a minimum of 19 miles to a maximum of 2,527 miles; rail route lengths would range from 20 miles to 2,620 miles. In general, risk will vary proportionally with the overall shipment length. 
TABLE 3 Summary of Transportation Route Distances from ETTP, Portsmouth, and Paducah to Commercial Fuel Fabricators

\begin{tabular}{|c|c|c|}
\hline \multirow[b]{2}{*}{ Origin/Destination } & \multicolumn{2}{|c|}{$\begin{array}{c}\text { Summary of } \\
\text { Route Distance } \\
\text { (miles) }\end{array}$} \\
\hline & Truck & Rail \\
\hline \multicolumn{3}{|l|}{ From ETTP to: } \\
\hline Westinghouse, Columbia, S.C. & 314 & 327 \\
\hline BWX Technologies, Lynchburg, Va. & 354 & 385 \\
\hline Framatome ANP, Richland, Wash. & 2,481 & 2,620 \\
\hline Global Nuclear Fuel, Wilmington, N.C. & 579 & 490 \\
\hline Nuclear Fuel Services, Erwin, Tenn. & 159 & 170 \\
\hline Metropolis, Ill. & 293 & 590 \\
\hline \multicolumn{3}{|l|}{ From Portsmouth to: } \\
\hline Westinghouse, Columbia, S.C. & 486 & 581 \\
\hline BWX Technologies, Lynchburg, Va. & 382 & 372 \\
\hline Framatome ANP, Richland, Wash. & 2,527 & 2,418 \\
\hline Global Nuclear Fuel, Wilmington, N.C. & 622 & 700 \\
\hline Nuclear Fuel Services, Erwin, Tenn. & 369 & 333 \\
\hline Metropolis, Ill. & 544 & 566 \\
\hline \multicolumn{3}{|l|}{ From Paducah to: } \\
\hline Westinghouse, Columbia, S.C. & 628 & 722 \\
\hline BWX Technologies, Lynchburg, Va. & 646 & 783 \\
\hline Framatome ANP, Richland, Wash. & 2,207 & 2,295 \\
\hline Global Nuclear Fuel, Wilmington, N.C. & 871 & 914 \\
\hline Nuclear Fuel Services, Erwin, Tenn. & 451 & 648 \\
\hline Metropolis, Ill. & 19 & 20 \\
\hline
\end{tabular}




\section{REGULATORY CONSIDERATIONS}

\subsection{UNITED STATES}

Commercial nuclear fuel fabrication facilities in the United States must obtain licenses from the NRC to manufacture, produce, receive, acquire, own, possess, use, or transfer byproduct, source, and special nuclear material (10 CFR 30.3; 10 CFR 40.3; 10 CFR 70.3). Each license specifies the authorized byproduct, source, and special nuclear materials, their chemical and/or physical forms, and the maximum quantity of each material that the licensee is allowed to possess at any one time. Each license further designates the purposes for which the authorized materials may be used. Hence, if DOE elects to transfer depleted $\mathrm{UF}_{6}$ to a commercial nuclear fuel fabrication facility for conversion to $\mathrm{UO}_{2}$, the NRC license held by the facility would need to authorize receipt, storage, conversion, and transfer of depleted uranium.

To evaluate whether a fuel fabrication facility's NRC license authorizes receipt, storage, conversion, and transfer of depleted uranium compounds, it is important to recognize that depleted uranium is source material, ${ }^{1}$ while uranium enriched in the isotope U-235 is special nuclear material. ${ }^{2}$ As such, authorizations for depleted uranium are typically specified separately in a facility's NRC license from authorizations for enriched uranium.

In Section 2, four commercial nuclear fuel fabrication facilities located in the United States were identified as having the capability to convert $\mathrm{UF}_{6}$ to $\mathrm{UO}_{2}$ : Westinghouse Electric Company LLC - Columbia Fuel Fabrication Facility; Framatome ANP Richland Division, Inc. - Engineering and Manufacturing Facility; Global Nuclear Fuel - Americas, LLC; and CE Nuclear Power LLC Hematite Fuel Manufacturing Operations. In addition, the Honeywell International Metropolis Works pilot plant has this capability. Because the Hematite facility is scaling down operations and will shut down after 2001, NRC license provisions for that facility were not investigated. The remaining three fuel fabrication facilities are authorized to receive uranium enriched up to $5 \mathrm{wt} \%$ U-235. However, none of the three has an NRC license that expressly authorizes receipt, storage, conversion, or transfer of depleted uranium in any form. Similarly, the Metropolis Works is authorized to receive natural uranium, but not depleted uranium. Therefore, it appears that a license amendment for appropriate authorizations regarding depleted uranium might have to be obtained by

\footnotetext{
1 "Source material" means: (1) uranium or thorium, or any combination thereof, in any physical or chemical form, or (2) ores which contain by weight one-twentieth of one percent $(0.05 \%)$ or more of: (i) uranium, (ii) thorium, or (iii) any combination thereof. Source material does not include special nuclear material (40 CFR 40.4).

2 "Special nuclear material" means: (1) plutonium, uranium-233, uranium enriched in the isotope 233 or in the isotope 235, and any other material which the NRC determines to be special nuclear material, but does not include source material; or (2) any material artificially enriched by any of the foregoing, but does not include source material (10 CFR 70.4).
} 
these facilities from the NRC before DOE could transfer depleted $\mathrm{UF}_{6}$ to them. Such an amendment would be routine and is unlikely to significantly deter using the conversion capacity at one or more of the facilities, provided the facilities are interested in supplying conversion services to DOE.

\subsection{FOREIGN COUNTRIES}

Sections 54, 64, 82, and 91 of the Atomic Energy Act (AEA) authorize DOE to export nuclear material under certain circumstances without obtaining an export license from the NRC. However, none of these circumstances appears to arise if DOE elects to transfer depleted $\mathrm{UF}_{6}$ to a foreign nuclear fuel fabrication facility for conversion to $\mathrm{UO}_{2}$. Therefore, in such a situation, Section 111 of the AEA would require DOE to obtain an export license from the NRC.

The regulations in 10 CFR Part 110, "Export and Import of Nuclear Equipment and Material," govern issuance by the NRC of export and import licenses. Such licenses may be general or specific. A general license, if applicable, is effective without the filing of an application or the issuance of licensing documents to a particular person. A specific license is issued to a named person and is effective upon approval by the NRC of an application and the issuance of licensing documents.

Because of the quantities of depleted $\mathrm{UF}_{6}$ in the DOE inventory requiring conversion, no general license would apply to the export of such material. Accordingly, a specific license for export would be required (10 CFR 110, Subpart C). However, the subsequent return of the converted $\mathrm{UO}_{2}$ to DOE should be covered by the general license for imports in 10 CFR 110.27(a), which authorizes any person to import byproduct, source, or special nuclear material if the consignee is authorized to possess the material.

Absent political considerations, obtaining a specific export license from the NRC should not be a significant deterrent to using conversion capacity at a foreign commercial fuel fabrication facility, if the foreign country does not object and the facility is willing to provide the service to DOE.

\subsection{TRANSPORTATION}

Shipments of $\mathrm{UF}_{6}$ to a commercial facility (see Section 3) would be made in accordance with all applicable transportation regulations. Shipment of depleted $\mathrm{UF}_{6}$ is regulated by the Department of Transportation (DOT) in 49 CFR Part 173, Subpart I, "Class 7 (Radioactive) Materials." Among other things, 49 CFR 173.420 requires that each $\mathrm{UF}_{6}$ cylinder be designed, fabricated, inspected, tested, and marked in accordance with the version of American National Standard N14.1, "Uranium Hexafluoride-Packaging for Transport" (ANSI N14.1) that was in effect 
at the time the cylinder was manufactured. Although a detailed discussion of depleted $\mathrm{UF}_{6}$ transportation requirements is not included in this report, three provisions in 49 CFR 173.420 and ANSI N14.1 are particularly important relative to depleted $U_{6}$ cylinder shipments: (1) a cylinder must be filled to less than $62 \%$ of the certified volumetric capacity (the fill-limit was reduced to $62 \%$ from 64\% around 1987); (2) the pressure within a cylinder must be less than 14.8 psia; and (3) a cylinder must be free of cracks, excessive distortion, bent or broken valves or plugs, and broken or torn stiffening rings or skirts, and must not have shell thicknesses that have decreased below a specified minimum value. Cylinders not conforming to these requirements are referred to as overfilled, overpressurized, and substandard, respectively. Any depleted UF ${ }_{6}$ currently stored in a nonconforming cylinder cannot be transported without some type of prior preparation, such as placement of the nonconforming cylinder in a DOT-approved overpack, or transfer of the depleted $\mathrm{UF}_{6}$ to a conforming cylinder.

Although definitive information is not currently available, preliminary reports suggest that many cylinders currently stored at ETTP, Portsmouth, and Paducah would either not meet DOT transportation requirements, or extensive time and effort would be required to demonstrate that they do (LLNL et al. 1997). This situation suggests that prior preparations, which may themselves be quite expensive and time consuming, are likely to be needed before transport could occur for a potentially large percentage of the stored cylinders in DOE's depleted UF ${ }_{6}$ inventory. 


\section{ANALYSIS AND CONCLUSIONS}

The current operating capability of commercial nuclear fuel fabricators to convert $\mathrm{UF}_{6}$ to $\mathrm{UO}_{2}$ in the United States is reported to be approximately 5,200 $\mathrm{tUF}_{6} / \mathrm{a}$, which includes $666 \mathrm{tUF}_{6} / \mathrm{a}$ of capacity scheduled for shutdown by the end of 2001. The pilot plant at the Honeywell International Metropolis Works could add an average of about $320 \mathrm{tUF}_{6} / \mathrm{a}$, if it were restarted and operated at its full capacity. Hence, the maximum rate of $\mathrm{UF}_{6}$ conversion, assuming all currently operating capacity in the United States could be devoted to converting DOE's depleted $\mathrm{UF}_{6}$ inventory, would be approximately 5,500 $\mathrm{tUF}_{6} / \mathrm{a}$. In comparison, DOE's depleted $\mathrm{UF}_{6}$ inventory consists of approximately 700,000 metric tons of depleted $\mathrm{UF}_{6}$. Consequently, more than 125 years would be required to convert this legacy inventory using commercially available capacity, even if all currently operating capacity were devoted to the task.

In an informal survey of U.S. commercial fuel cycle facilities conducted during preparation of this report, only about $300 \mathrm{tUF}_{6} / \mathrm{a}$ of existing capacity could be confirmed as being possibly available to DOE. While additional capacity at commercial facilities might later become available, there seems to be a general lack of interest on the part of the facility owners in committing existing operating or mothballed capacity ${ }^{3}$ to conversion of the DOE depleted $\mathrm{UF}_{6}$ inventory.

Route length is the primary factor in distinguishing both cost and risk associated with shipment of depleted $\mathrm{UF}_{6}$ to different locations. Therefore, the distance between the U.S. commercial fuel cycle facilities and the DOE depleted $\mathrm{UF}_{6}$ storage sites would be one factor to consider in evaluating whether any particular commercial fuel cycle facility should be used. As this report indicates, such distances vary considerably.

It appears that NRC license amendments might be needed before U.S. commercial fuel cycle facilities could receive and process depleted $\mathrm{UF}_{6}$. However, this should not be a significant deterrent to using the conversion capacity at one or more of the facilities, provided the facilities are interested in furnishing conversion services to DOE. A greater regulatory concern may arise with respect to transporting a large percentage of the depleted $\mathrm{UF}_{6}$ inventory to such facilities. Although definitive information is not currently available, preliminary reports suggest that many cylinders currently stored at ETTP, Portsmouth, and Paducah would either not meet DOT transportation requirements, or extensive time and effort would be required to demonstrate that they do. This situation suggests that prior preparations, which may be quite expensive and time-consuming, are likely to be needed before transport could occur for a potentially large percentage of the stored cylinders.

3 No publicly accessible information indicated the amount of mothballed capacity at any facility investigated for this report. Also, no information was solicited directly from such facilities regarding mothballed capacity. 
The current operating capability of commercial nuclear fuel fabricators in foreign countries to convert $\mathrm{UF}_{6}$ to $\mathrm{UO}_{2}$ is reported to total approximately $23,000 \mathrm{tUF}_{6} / \mathrm{a}$. For the purpose of this report, no effort was made to determine whether any of this foreign capacity could be available to DOE. However, even if all of it were available, about 30 years would be needed to convert DOE's depleted $\mathrm{UF}_{6}$ inventory at this rate. If only $10 \%$ of the foreign capacity were available, it would take about 300 years to complete the effort. In addition, there would be regulatory and political considerations that would need to be factored into any decision to utilize foreign facilities for conversion of DOE's depleted $\mathrm{UF}_{6}$ inventory. 


\section{REFERENCES}

ANF, 2000, "Beitrebsstätte Lingen,” Advanced Nuclear Fuels GmbH, available from: http://lingenems.de/firmen/advanced.html (accessed on Dec. 28, 2000).

Chicago Tribune, 2001, "EC Probe Delays Honeywell Buyout," published on February 28, 2001, available from: http://chicagotribune.com/tools/search/archives/form (accessed on April 18, 2001).

EIA, 1998, Challenges of Electric Power Industry Restructuring for Fuel Suppliers, DOE/EIA-0623, Energy Information Administration, U.S. Department of Energy, Washington, D.C., September.

IAEA, 2001a, "Nuclear Fuel Cycle Facility - Report, W Defluorinat (Depl. UF6)," International Atomic Energy Agency, Nuclear Fuel Cycle Information System, available from: http://www-nfcis. iaea.org/NFCFacilityReport.asp?WhichFacility=78 (accessed on April 18, 2001).

IAEA, 2001b, "Nuclear Fuel Cycle Facility - Report, BNFL Springfield OFC IDR UO2 Line," International Atomic Energy Agency, Nuclear Fuel Cycle Information System, available from: http://www-nfcis.iaea.org/NFCFacilityReport.asp?WhichFacility=585 (accessed on April 18, 2001).

IAEA, 2001c, "Nuclear Fuel Cycle Facility - Report, Mitsubushi Nuclear Fuel Ltd. (MNF)," International Atomic Energy Agency, Nuclear Fuel Cycle Information System, available from: http://www-nfcis. iaea.org/NFCFacilityReport.asp?WhichFacility=709 (accessed on April 18, 2001).

IAEA, 2001d, "Nuclear Fuel Cycle Facility - Report, FBFC International," International Atomic Energy Agency, Nuclear Fuel Cycle Information System, available from: http://www-nfcis. iaea.org/NFCFacilityReport.asp? WhichFacility=110 (accessed on April 18, 2001).

IAEA, 2001e, "Nuclear Fuel Cycle Facility - Report, Resende - Unit 2,'International Atomic Energy Agency, Nuclear Fuel Cycle Information System, available from: http://www-nfcis. iaea.org/NFCFacilityReport.asp? WhichFacility=784 (accessed on April 18, 2001).

Johnson P.E., and R.D. Michelhaugh, 2000, Transportation Routing Analysis Geographic Information System (WebTragis) User's Manual, ORNL/TM-2000/86, Oak Ridge National Laboratory, Oak Ridge, Tenn., April.

KNFC, 2000a, "Supply of Nuclear Fuel \& Production Capacity," Korea Nuclear Fuel Co., Ltd., available from: http://www.knfc.co.kr/home/ecapa.htm, Production (accessed on Dec. 28, 2000).

KNFC, 2000b, "PWR Fuel Fabrication Process," Korea Nuclear Fuel Co., Ltd., available from: http://www.knfc.co.kr/home/epwrpro.htm (accessed on Dec. 28, 2000). 
LLNL et al., 1997, Depleted Uranium Hexafluoride Management Program; the Draft Engineering Analysis Report for the Long-Term Management of Depleted Uranium Hexafluoride, UCRL-AR124080, Volumes I and II, prepared by Lawrence Livermore National Laboratory, Science Applications International Corporation, Bechtel, and Lockheed Martin Energy Systems for U.S. Department of Energy, 1997.

Maas, L.J., 2001, Comments on "Excerpt from Draft Evaluation of $\mathrm{UF}_{6}$-to- $\mathrm{UO}_{2}$ Conversion Capability at Commercial Nuclear Fuel Fabrication Facilities," fax to Nancy L. Ranek, Argonne National Laboratory, March 21.

Siemens Power Corporation, 2000, Letter (from L.J. Maas) to the U.S. Nuclear Regulatory Commission (Document Control Desk) regarding Request for NRC Consent for Transfer of Siemens Power Corporation's (SPC's) Materials License (Docket 70-1257) and Related Licenses, Certificates and Approvals, Sept. 29.

WEC, 2000a, Letter from Westinghouse Electric Company (R.W. Sharkey) to the U.S. Nuclear Regulatory Commission (Director, Office of Nuclear Materials Safety and Safeguards) regarding Amendment Request to License SNM-33 Application Pages, June 2.

WEC, 2000b, "BNFL/Westinghouse Complete Acquisition of ABB's Nuclear Businesses," Press Release (May 1, 2000), Westinghouse Electric Company, available from: http://www. westinghouse.com (accessed on Dec. 28, 2000).

WEC, 2000c, "Nuclear Fuel," Westinghouse Electric Company, available from: http://www. westinghouse.com/atom, Products (accessed on December 28, 2000). 


\section{APPENDIX}

\section{RECORDS OF TELEPHONE SURVEY}

Between January 29 and February 2, 2001, Argonne National Laboratory staff contacted most of the commercial nuclear fuel fabrication facilities in the United States, as well as the Honeywell International Metropolis Works Plant, which converts natural uranium oxide to $\mathrm{UF}_{6}$. The primary purpose of this informal verbal survey was to inquire about whether these facilities have conversion capacity that they would consider dedicating for use by DOE if, hypothetically, DOE were to decide to use such capacity to convert some or all of its depleted $\mathrm{UF}_{6}$ inventory. During March 2001, each facility was asked to review and suggest corrections and additions to the record of the telephone survey and the section of the main report pertaining to its operations. The final records of the telephone survey are provided in this appendix.

Westinghouse Electric Company LLC - Columbia, South Carolina

Individual Contacted: $\quad$ David Precht

Phone: $\quad 803 / 647-3485$

Date and Time of Contact: Mr. Precht did not respond to messages.

Contacted By: $\quad$ Nancy L. Ranek

BWX Technologies, Inc. - Lynchburg, Virginia

Individual Contacted: $\quad$ Arne F. Olsen, Licensing Officer

Phone: $\quad 804 / 522-5174$

Date and Time of Contact: January 30, 2001; 9:00 a.m. Eastern

Contacted By: $\quad$ Nancy L. Ranek

Mr. Olsen reported that BWXT has no process capability to convert $\mathrm{UF}_{6}$ to $\mathrm{UO}_{2}$. However, at one time, BWXT was bidding on a contract to clean heels from empty UF ${ }_{6}$ cylinders. For this reason, the license that BWXT holds from the NRC was amended to authorize receipt of $\mathrm{UF}_{6}$ heels. 
Even so, BWXT did not receive the contract, and consequently, has no experience with handling of $\mathrm{UF}_{6}$.

Mr. Olsen was unable to say whether BWXT would be interested in making process changes to accommodate conversion of $\mathrm{UF}_{6}$ from the DOE inventory to $\mathrm{UO}_{2}$ at the Lynchburg facility.

Mr. Olsen indicated he would pose this question to others at BWXT and call back later.

On February 27, 2001, Mr. Olsen called to report that BWXT is investigating the possibility of process changes that would accommodate depleted $\mathrm{UF}_{6}$ conversion at its Lynchburg plant.

CE Nuclear Power LLC - Hematite, Missouri

Individual Contacted: None.

Phone:

Date and Time of Contact: Because this facility plans to discontinue operations by the end of 2001, no contact was made.

Contacted By:

Framatome Advanced Nuclear Power Richland Division, Inc. (formerly Siemens Power Corporation) - Richland, Washington

Individual Contacted: $\quad$ (1) L.J. Maas, Manager, Regulatory Compliance

(2) Mr. Robin Feuerbacher, Vice President for Engineering and Manufacturing

Phone: $\quad$ (1) $509 / 375-8537$

(2) $509 / 375-8267$

Date and Time of Contact: (1) January 29, 2001; 12:36 p.m. Eastern

(2) January 31,$2001 ; 12: 15$ p.m. Eastern

Contacted By: Nancy L. Ranek 
Mr. Maas indicated that Siemens is a member of one of the teams responding to the DOE Request for Proposals to construct and operate $\mathrm{UF}_{6}$ conversion facilities at Portsmouth and Paducah.

Mr. Maas was unable to say whether Framatome ANP would be interested in dedicating any excess capacity to conversion of $\mathrm{UF}_{6}$ from the DOE inventory to $\mathrm{UO}_{2}$ at the Richland facility.

Mr. Maas stated that he would pose the question to others at Framatome ANP and call back.

Mr. Robin Feuerbacher called back on January 31, 2001.

Mr. Feuerbacher stated that Framatome ANP has three process lines at the Richland facility. They may be willing to devote one of these lines to converting DOE's depleted $\mathrm{UF}_{6}$, although this is reserve capacity for unexpected orders from customers or affiliates. This would provide capacity to convert approximately 300 metric tons/year of $\mathrm{UF}_{6}$ to $\mathrm{UO}_{2}$. However, Mr. Feuerbacher indicated that the Richland plant receiving facilities are designed for Model No. 30B cylinders. Modifications and associated license amendments would be required to receive 48 -inch cylinders.

Currently the Richland facility processes very little depleted $\mathrm{UF}_{6}$, because it is a neutron poison which, if not completely cleaned from the process lines, can contaminate the plant's normal fuel product. In addition, because the normal product is enriched uranium fuel, the plant is designed for criticality control. Mr. Feuerbacher noted that such control is not needed for depleted $\mathrm{UF}_{6}$, and utilizing equipment designed for enriched uranium reduces the efficiency with which the depleted $\mathrm{UF}_{6}$ could otherwise be processed.

Regarding transportation access, Mr. Feuerbacher indicated that the plant currently handles all incoming and outgoing shipments by truck. However, he reported that the plant is about 0.5 mile from a rail line and about 3 miles from the Columbia River. Therefore, he believes that truck, rail, and barge are all possible modes of transport for incoming depleted $\mathrm{UF}_{6}$ and outgoing uranium oxide product.

Regarding the Richland facility's NRC license, Mr. Feuerbacher stated his belief that the existing license, which authorizes receipt of uranium enriched up to $5 \%$, would cover receipt of depleted uranium, but the State of Washington license may have to be amended to increase the possession limit for source material. 
Framatome Advanced Nuclear Power, Inc.

(formerly Framatome Cogema Fuels) - Lynchburg, Virginia

Individual Contacted: $\quad$ Robert S. Freeman, Manager, Regulatory Affairs

Phone: $\quad$ 804/832-5268

Date and Time of Contact: January 29, 2001; 7:10 p.m. Eastern

Contacted By: $\quad$ Nancy L. Ranek

Mr. Freeman confirmed that the Framatome ANP facility in Lynchburg, Virginia, has no on-site conversion capability. Therefore, the facility would not be able to provide $\mathrm{UF}_{6}$ conversion services to DOE.

Global Nuclear Fuel-Americas, LLC - Wilmington, North Carolina

Individual Contacted: Charles M. Vaughn, Manager, Facility Licensing

Phone: 910/675-5656

Date and Time of Contact: January 29, 2001; 3:40 p.m. Eastern

Contacted By: $\quad$ Nancy L. Ranek

Mr. Vaughn stated that Global Nuclear Fuel - Americas would not be interested in dedicating any excess capacity to conversion of $\mathrm{UF}_{6}$ from the DOE inventory to $\mathrm{UO}_{2}$ at the Wilmington facility. 
Nuclear Fuel Services, Inc. - Erwin, Tennessee

Individual Contacted: $\quad$ Frank J. Hahne, Vice President, Business Development \& Projects

Phone: 423/743-1789

Date and Time of Contact: January 29, 2001; 1:15 p.m. Eastern

Contacted By: $\quad$ Nancy L. Ranek

Mr. Hahne indicated that the NFS facility has some limited capability to convert $\mathrm{UF}_{6}$ to $\mathrm{UO}_{2}$. However, the facility handles primarily highly enriched uranium. Furthermore, the facility has no capability to handle 48-inch $\mathrm{UF}_{6}$ cylinders.

Mr. Hahne stated that NFS would be interested in making facility and equipment modifications to accommodate conversion of depleted $\mathrm{UF}_{6}$ from the $\mathrm{DOE}$ inventory to $\mathrm{UO}_{2}$ at the Erwin facility.

Mr. Hahne pointed out that the NRC license held by NFS allows receipt of empty $\mathrm{UF}_{6}$ cylinders containing heels. Accordingly, Mr. Hahne expressed his belief that NFS would be interested in receiving empty $\mathrm{UF}_{6}$ cylinders containing enriched heels, if DOE decides to seek such services.

Honeywell International, Metropolis Works - Metropolis, Illinois

Individual Contacted: $\quad$ J. William Lessig, Plant Manager

Phone:

$618 / 524-2111$

Date and Time of Contact: February 1, 2001; 11:30 a.m. Eastern

Contacted By: $\quad$ Nancy L. Ranek

Mr. Lessig stated that the pilot plant that was built at the Metropolis Works and operated during the late 1990s is shut down. Notwithstanding, he stated that some of the plant's customers have from time to time expressed an interest in obtaining $\mathrm{UF}_{6}$ to uranium oxide conversion services for small amounts of $\mathrm{UF}_{6}$. He was unable to say, however, whether Converdyn (the marketer of Metropolis Works products) would be willing to restart the plant for the purpose of providing conversion services for DOE's depleted $\mathrm{UF}_{6}$ inventory. He requested that ANL contact Mr. Jim 
Graham at Converdyn's Denver, Colorado, offices [303/930-4901]. Mr. Lessig reported that if the pilot plant were operated at full capacity, it could convert between 300 and 400 tons (U.S.) per year of $\mathrm{UF}_{6}$ to $\mathrm{UO}_{2}$.

Mr. Graham (at Converdyn) did not respond to messages. 